\title{
Assessing the geo-electric characteristics of Basement Complex rocks and its implication for groundwater prospecting in Ilorin Metropolis, Nigeria
}

\author{
I. P. Ifabiyi ${ }^{1}$, E. D. Ashaolu ${ }^{2}$ and O. Omotosho ${ }^{3}$ \\ Department of Geography and Environmental Management, University of Ilorin, Ilorin, \\ Nigeria \\ Correpondence: ${ }^{1}$ tokunifabiyi@yahoo.com, ${ }^{2}$ damash007@yahoo.com \\ ${ }^{3}$ olumideomotosho47@gmail.com
}

Received: $6^{\text {th }}$ October 2016, Revised: $21^{\text {st }}$ December 2016, Accepted: $24^{\text {th }}$ December 2016

\begin{abstract}
In Basement Complex rocks where rainfall is seasonal, water provision in dry season depends on regolith aquifer. For effective exploitation of groundwater resources, it is reasonable that geophysical investigation be conducted before development of well. In many instances, geophysical surveys may be expensive or nonexistent. Hence, there is a need for spatial analysis which might advise water engineers within such environments. Vertical Electrical Soundings (VES) data of 53 locations conducted with ABEM SAS-1000 terrameter using Schlumberger electrode configuration were obtained from the hydrogeology Department of Kwara state Ministry of Water Resources and Lower Niger River Basin and Rural Development Authority, Ilorin. VES locational coordinates were recorded using handheld GPS device. Sound curves were evaluated by partial curve matching approach and computer iteration using WinResist. The results depict six geo-electric regional successions, namely: top soil, lateritic clay, weathered basement, fairly-hard basement, thin fractured and hard basement. The geo-electric succession identified was plotted in Surfer 12 environment, using kriging interpolation method to show spatial distribution pattern of this zone. The spatial pattern is expected to give an insight to the nature of spatial variability of geo-electric layers and assist drillers as well as water resources policy makers in their operations.
\end{abstract}

Keywords. Geo-electric, groundwater, basement complex, geophysical, GIS

\section{Introduction}

Groundwater occurrence is often localized and confined to weathered or fractured zones in the Basement Complex region, and groundwater exploration in such terrain is always complex. The crystalline basement rocks 
have low porosity and permeability, hence, have no water storage capacity in their unaltered form; which makes their groundwater prospects to be limited and often restricted to features produced by weathering and tectonic processes (Olayinka and Olorunfemi, 1992; Olorunfemi and Fasuyi, 1993; Oyedele et al., 2013). In tropical basement rock, weathering process creates superficial layers, with varying degrees of porosity and permeability. This unconsolidated superficial layers, if significantly thick, porous and permeable, makes good aquifer units. It is important to note that the concealed basement rock may contain faulted areas, incipient joints and fracture systems derived from earlier tectonic processes in such region. The detection and delineation of these hydro-geologic structures may facilitate the location of groundwater potential zones in a typical basement rock environment (Omosuyi, et al., 2003; Oyedele, et. al., 2013).

Olorunfemi and Fasuyi (1993) submitted that the highest groundwater yield in basement terrains is found in areas where thick overburden overlies fractured zones. These fractured zones are often characterized by relatively low resistivity values. Olayinka and Olorunfemi (1992) argued that before a borehole is sited, a surface geophysical survey such as Vertical Electrical Resistivity Sounding (VES) should be conducted to identify the localized aquifer for a productive well. The Vertical Electrical Resistivity Sounding survey provides information about the subsurface that aid in aquifer delineation and identification of lithologic boundaries and geological structures (Bose, et al., 1973; Abiola, et al., 2013).

Vertical Electrical Resistivity Sounding method has been used widely by scholars in groundwater prospecting especially in the Basement Complex terrains to get detailed information about hydrogeological settings for groundwater potentials (Olorunfemi, 1990; Olorunfemi and Olayinka, 1992; Olorunfemi and Fasuyi, 1993; Oladapo, et al., 2009; Anohanmoran. 2013; Ogundana and Talabi, 2014). VES is used to determine the vertical variation of electrical resistivity below the earth surface and the potential field generated by the current, and this is because electrical resistivity of most rock depends on the amount of water in their pores. This method proved useful in groundwater studies because neither the structure nor the dynamics of the soil was disturbed (Otobo and Ifedili, 2005; Adiat et al., 2009; Ariyo and Adeyemi, 2009; Anomoharan, 2011; Anomoharan, 2013).

Despite the importance of VES in groundwater prospecting in a Basement Complex terrain, a better interpretation of hydrogeological data generated from this method often requires that their spatial location be incorporated into the analysis (Shahid and Nath, 2002). This will reveal the spatial variation of different geo-electric section of Basement Complex rock which can give a 
better understanding of the hydrogeological prospect, especially of a large area. Consequently, the incorporation of Geographical Information System (GIS) into studies of groundwater prospecting becomes imperative. According to Shahid and Nath (2002), in recent time, GIS is widely used for spatial modeling of hydrogeological prospect of a large area with more reliability on groundwater exploration. Further, GIS has proved to be an efficient tool in groundwater researches and the inclusion of subsurface information deduced from geo-electric survey can give more realistic picture of groundwater potentiality of an area (Saraf, et.al., 1998; Krishnamurthy, et.al., 1996; Murthy, 2000; Shahid and Nath, 2002; Amaresh and Ravi Prakash, 2003).

Ilorin city is underlain by Precambrian Basement Complex; comprising mostly gneiss, granite, schist, undifferentiated meta-sediments rocks and overburden that are composed mainly of clay, sand and silt soils. The residents of this area often augment the public water supply by the Kwara State Water Corporation with groundwater (shallow and deep) because the supply is erratic and unreliable (Ifabiyi and Ahmed, 2011) and the coverage is limited to some areas (Ifabiyi and Ashaolu, 2013). The population of this city is rapidly increasing as new residential areas have sprung up and continue springing up in the last decade. All these new residential areas depend solely on groundwater for their domestic needs. On this basis, this study assessed and mapped the geo-electric characteristics of Basement Complex Rock of Ilorin, Nigeria in order to identify their spatial variation and implication on groundwater prospects of the city.

\section{Material and Methods}

\subsection{The study area}

Ilorin the Kwara state capital is located between latitude $08^{\circ} 24^{\prime} \mathrm{N}$ and $08^{\circ} 38^{\prime} \mathrm{N}$ of the equator, and longitude $04^{\circ} 26^{\prime} \mathrm{E}$ and $04^{\circ} 37^{\prime} \mathrm{E}$ of the Greenwich meridian, and covers about $12 \mathrm{~km}$. Ilorin is one of the fastest growing urban centers in Nigeria. There has been a huge increase in the population of Ilorin since it became the state capital in 1976. The population growth rate is much higher than other cities at 2.9 percent of the national growth rate. The 2006 census put the population of Ilorin city to about 847,582 (NPC, 2006 provisional results). Ilorin has a tropical wet and dry climate. Wet season is experienced from April to October and dry season from November to March. Rainfall condition in Ilorin exhibits greater variability both temporarily and spatial. The annual mean rainfall is about $1,200 \mathrm{~mm}$, exhibiting the double maximal pattern between April and October of every year. Relative humidity varies seasonally with an average of $79.7 \%$. 
The city is underlain by Precambrian Basement Complex, comprising mostly gneiss, granite, schist, undifferentiated meta-sediments rocks and overburden that are composed mainly of clay, sand and silt soils. The underlying pre-Cambrian igneous-metamorphic rock of Basement Complex is neither porous nor permeable except in places where they are deeply weathered or have zones of weakness. Some part of the town is also laid by Sedimentary rocks, which contains both primary and secondary laterites and alluvial deposits. Groundwater on the alluvium is recharged directly by rainfall or the adjoining overflowing river system. In the dry season, the alluvium sustains considerable subsurface groundwater flow. The alluvial deposits have been exploited, with successful wells and boreholes in Ilorin metropolis and its surrounding. The drainage system of Ilorin is dendritic in nature, and is dominated by Asa River, which flows from south to north and divides the city into two parts, the western and eastern parts. The map of the study area is presented in Figure 1.

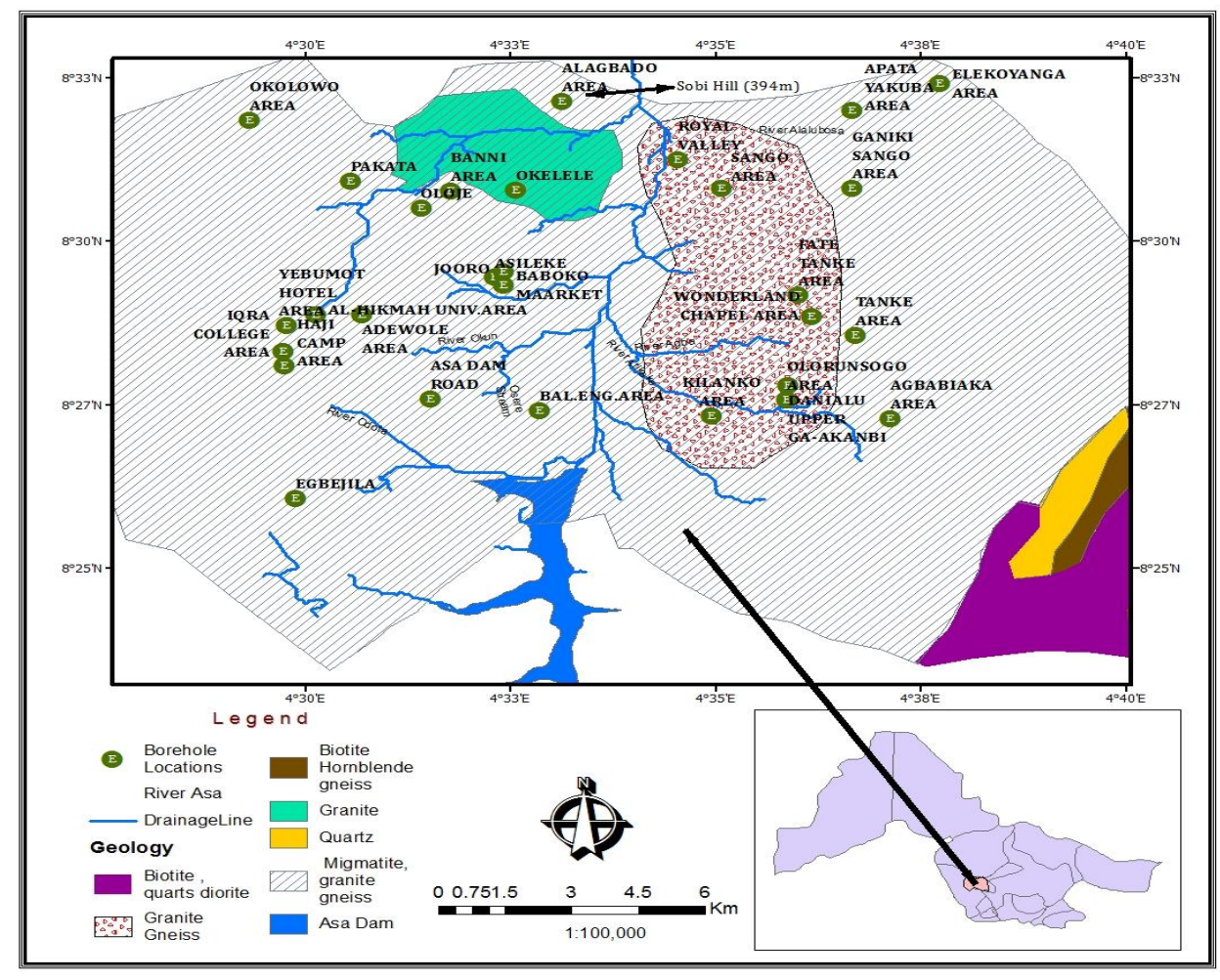

Fig 1. Geological map of the study area showing the sampled points 


\subsection{Methods}

This study adopted the combination of secondary and primary (field work) data. The secondary data collected are the Vertical Electrical Soundings (VES) data conducted by the Kwara State Ministry of Water Resources and Lower Niger River Basin Development Authority, Ilorin. All the Vertical Electrical Soundings (VES) data collected were conducted with ABEM SAS1000 Terrameter using the Schlumberger electrode configuration, and the electrode spacing $(\mathrm{AB} / 2)$ varied from $0.1 \mathrm{~m}$ to $200 \mathrm{~m}$. The results of geophysical survey carried out in 53 different locations in Ilorin were collected. The minimum number of VES carried out in each of these 53 locations was 9 and the maximum were 12. The sounding curves were evaluated by partial curve matching method and computer iterations using WinResist. The field work was carried out to get the coordinates (locations) of the sampled points using handheld Global Positioning System device. This was carried out to get the coordinates of all the locations used in the study, which facilitated the plotting of the data in Surfer 12 GIS software. The resistivity values from the interpretation of the field data using curve matching were used to generate geo-electrical succession. The data on geoelectric layers and the point location collected were used to plot the geoelectric map of the study area. This was carried out in Surfer 12 GIS software using kriging interpolation method to determine the spatial distribution of the identified layers in the study area.

\section{Results and Discussion}

\subsection{General Pattern of Geophysical Characteristics of Groundwater in Ilorin}

The identified layers resistivity and thickness ranges across the sampled points in the study area are presented in Table 1. From the table, six regional geo-electric patterns are discernable, namely: top lateritic sand, lateritic clay, weathered basement, fairly hard basement, thin fractured and hard basement. However, the study looks at the vertical variations of the electrical resistivity recorded from one point to another across the study area, hence, overlaps observed in the reported VES range. The first layer consists of the top soil with resistivity values ranging from 30-3000 ohm-m and thickness ranging from $0.2-1.0 \mathrm{~m}$. The lateritic clay layer is where resistivity ranges between $23-$ $1400 \mathrm{Ohm}-\mathrm{m}$ and thickness from $2-20 \mathrm{~m}$. The third lithologic layer is characterized by highly weathered basement with resistivity values between $22-1000 \mathrm{Ohm}-\mathrm{m}$ and thickness of 2-45 m. Electrical resistivity values here are controlled by the degree of water saturation (Odunsanya and Amadi, 1990; Oladipo et al., 2009). 
Table 1: Ranges of geo-electric succession in Ilorin, Nigeria

\begin{tabular}{llll}
\hline SN & Layers & $\begin{array}{l}\text { Resistivity } \\
\text { (ohms) }\end{array}$ & Thickness (m) \\
\hline 1 & Top Lateritic Soil & $30-3000$ & $0.2-1.0$ \\
2 & Lateritic Clay & $23-1400$ & $2-20$ \\
3 & Weathered Basement & $25-1000$ & $2-45$ \\
4 & Fairly Hard Basement & $22-600$ & $6-42$ \\
5 & Thin Fractured & $55-145$ & $20-40$ \\
6 & Hard Basement & $35-780$ & $15-42$ above \\
\hline
\end{tabular}

The fourth layer is a fairly hard basement weathered and resistivity ranging from $22-600 \mathrm{ohm}-\mathrm{m}$ and thickness between $6-42 \mathrm{~m}$. The fifth layer represents a thin fractured zone and resistivity ranging from 55- $145 \mathrm{Ohm}-\mathrm{m}$ and thickness between $20-40 \mathrm{~m}$. The sixth layer represents the hard basement with resistivity values ranging from $35-780 \mathrm{Ohm}-\mathrm{m}$ and thickness between $15-$ $42 \mathrm{~m}$ and above across the study area. Figure 2 and Table 2 show the resistivity value of each geo-electric succession in the 53 sampled locations across the study area.

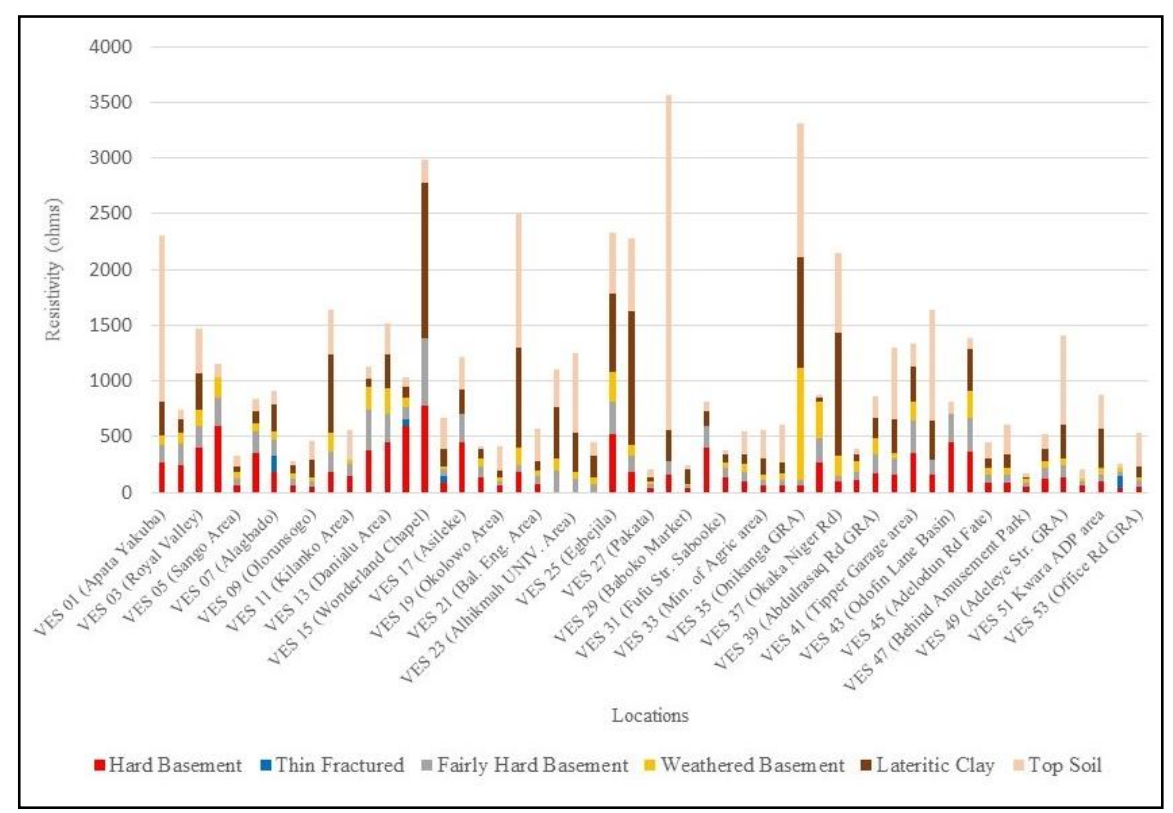

Fig 2. Geo-electric section of Vertical Electrical Sounding in Ilorin Metropolis 
Table 2: Geo-electric succession in the study area (Res: Resistivity $\Omega-\mathrm{m}$; T: Thickness, $\mathrm{m}$ )

\begin{tabular}{|c|c|c|c|c|c|c|c|c|c|c|c|c|c|}
\hline \multirow[t]{2}{*}{$\mathrm{SN}$} & \multirow[t]{2}{*}{ Description } & \multicolumn{2}{|c|}{$\begin{array}{c}\text { Top } \\
\text { Lateritic } \\
\text { Soil } \\
\end{array}$} & \multicolumn{2}{|c|}{$\begin{array}{c}\text { Lateritic } \\
\text { Clay }\end{array}$} & \multicolumn{2}{|c|}{$\begin{array}{l}\text { Weathered } \\
\text { Basement }\end{array}$} & \multicolumn{2}{|c|}{$\begin{array}{c}\text { Fairly } \\
\text { Hard } \\
\text { Basement }\end{array}$} & \multicolumn{2}{|c|}{$\begin{array}{c}\text { Thin } \\
\text { fractured }\end{array}$} & \multicolumn{2}{|c|}{$\begin{array}{c}\text { Hard } \\
\text { Basement }\end{array}$} \\
\hline & & $\begin{array}{c}\text { Res. } \\
(\Omega-\mathrm{m})\end{array}$ & $\begin{array}{c}\mathrm{T} \\
(\mathrm{m})\end{array}$ & $\begin{array}{l}\text { Res. } \\
(\Omega-\mathrm{m})\end{array}$ & $\begin{array}{c}\mathrm{T} \\
(\mathrm{m})\end{array}$ & $\begin{array}{l}\text { Res. } \\
(\Omega-\mathrm{m})\end{array}$ & $\begin{array}{l}\mathrm{T} \\
(\mathrm{m})\end{array}$ & $\begin{array}{c}\text { Res. } \\
(\Omega-\mathrm{m})\end{array}$ & $\begin{array}{c}\mathrm{T} \\
(\mathrm{m}) \\
\end{array}$ & $\begin{array}{c}\text { Res. } \\
(\Omega-\mathrm{m})\end{array}$ & $\begin{array}{l}\mathrm{T} \\
(\mathrm{m})\end{array}$ & $\begin{array}{c}\text { Res. } \\
(\Omega-\mathrm{m})\end{array}$ & $\begin{array}{c}\mathrm{T} \\
(\mathrm{m})\end{array}$ \\
\hline 1 & Apata Yakuba & 1500 & $0-1$ & 300 & $2-3$ & 80 & $3-20$ & 160 & $20-40$ & 0 & 0 & 270 & 40-above \\
\hline 2 & Ganiki Sango & 85 & $0-1$ & 130 & $2-6$ & 90 & $6-20$ & 190 & $20-35$ & 0 & 0 & 250 & 35-above \\
\hline 3 & Royal Valley & 400 & $0-1$ & 320 & $2-3$ & 145 & $3-15$ & 200 & $15-30$ & 0 & 0 & 400 & 30-above \\
\hline 4 & Elekoyangan & 120 & $0-1$ & NA & NA & 180 & $2-15$ & 250 & $15-20$ & 0 & 0 & 600 & 20-above \\
\hline 5 & Sango Area & 100 & $0-1$ & 50 & $2-10$ & 65 & $10-30$ & 52 & $30-40$ & 0 & 0 & 68 & 40-above \\
\hline 6 & Oyun Area & 100 & $0-1$ & 120 & $2-3$ & 65 & $3-10$ & 200 & $10-30$ & 0 & 0 & 350 & 30-above \\
\hline 7 & Alagbado & 120 & $0-1$ & 250 & $2-6$ & 70 & $6-20$ & 150 & $20-35$ & 145 & $35-40$ & 180 & 40-above \\
\hline 8 & Okelele & 30 & $0-1$ & 68 & $2-8$ & 52 & $8-25$ & 60 & $25-35$ & 0 & 0 & 66 & 35-above \\
\hline 9 & Olorunsogo & 170 & $0-1$ & 160 & $2-3$ & 35 & $3-20$ & 40 & $20-40$ & 0 & 0 & 55 & 40-above \\
\hline 10 & Agbabiaka area & 400 & $0-1$ & 700 & $2-15$ & 170 & $15-30$ & 180 & $30-40$ & 0 & 0 & 190 & 42-above \\
\hline 11 & Kilanko Area & 270 & $0-1$ & NA & NA & 35 & $2-20$ & 110 & $20-40$ & 0 & 0 & 150 & 40-above \\
\hline 12 & Tanke Area & 110 & $0-1$ & 80 & $2-20$ & 200 & $20-40$ & 365 & $40-40$ & 0 & 0 & 380 & 42-above \\
\hline 13 & Danialu & 280 & $0-1$ & 300 & $2-3$ & 225 & $3-20$ & 260 & $20-30$ & 0 & 0 & 450 & 30-above \\
\hline 14 & Fate Tanke & 80 & $0-1$ & 100 & $2-5$ & 90 & $5-10$ & 105 & $10-20$ & 55 & $20-30$ & 600 & $15-30$ \\
\hline 15 & $\begin{array}{l}\text { Wonderland } \\
\text { Chapel }\end{array}$ & 200 & $0-1$ & 1400 & $2-15$ & 0 & 0 & 600 & $15-30$ & 0 & 0 & 780 & 30-above \\
\hline 16 & Oloje Area & 270 & $0-1$ & 160 & $2-5$ & 32 & $5-6$ & 58 & $20-30$ & 60 & $30-35$ & 85 & 35-above \\
\hline 17 & Asileke & 290 & $0-1$ & 220 & $2-15$ & 0 & 0 & 250 & $15-25$ & 0 & 0 & 450 & 25-above \\
\hline 18 & Jooro & 25 & $0-1$ & 85 & $2-10$ & 72 & $10-20$ & 100 & $20-35$ & 0 & 0 & 130 & 30-above \\
\hline 19 & Okolowo Area & 220 & $0-1$ & 70 & $2-3$ & 30 & $3-20$ & 40 & $20-40$ & 0 & 0 & 60 & 42-above \\
\hline 20 & Yebumot Area & 1200 & $0-1$ & 900 & $2-10$ & 150 & $10-35$ & 70 & $35-42$ & 0 & 0 & 180 & 42-above \\
\hline 21 & Bal. Eng. Area & 300 & $0-1$ & 80 & $2-6$ & 52 & $6-30$ & 65 & $30-40$ & 0 & 0 & 80 & 40-above \\
\hline 22 & Hajj Camp & 340 & $0-1$ & 450 & $2-6$ & 110 & $6-20$ & 200 & $20-40$ & 0 & 0 & 0 & 0 \\
\hline 23 & $\begin{array}{l}\text { Alhikmah } \\
\text { UNIV. Area) }\end{array}$ & 710 & $0-1$ & 350 & $2-6$ & 60 & $6-25$ & 125 & $25-40$ & 0 & 0 & 0 & 0 \\
\hline 24 & Adewole Area & 120 & $0-1$ & 200 & $2-10$ & 50 & $10-30$ & 80 & $30-40$ & 0 & 0 & 0 & 0 \\
\hline 25 & Egbejila & 550 & $0-1$ & 700 & $2-8$ & 260 & $8-45$ & 300 & $15-25$ & 0 & 0 & 520 & 25-above \\
\hline 26 & Asa Dam & 650 & $0-1$ & 1200 & $2-8$ & 100 & $8-20$ & 150 & $20-40$ & 0 & 0 & 180 & 42-above \\
\hline 27 & Pakata & 80 & $0-1$ & 30 & $2-6$ & 25 & $6-15$ & 35 & $15-30$ & 0 & 0 & 40 & 30-above \\
\hline 28 & Iqra college & 3000 & $0-1$ & 280 & 25 & 0 & 0 & 120 & $8-40$ & 0 & 0 & 160 & 40-above \\
\hline 29 & Baboko Market & 38 & $0-1$ & 130 & $2-5$ & 13 & $5-30$ & 22 & $30-40$ & 0 & 0 & 40 & 40-above \\
\hline 30 & Banni Area & 80 & $0-1$ & 130 & $2-6$ & 0 & 0 & 200 & $6-23$ & 0 & 0 & 400 & 25-above \\
\hline 31 & $\begin{array}{l}\text { Fufu Str. } \\
\text { Sabooke }\end{array}$ & 32 & $0-1$ & 74 & $2-10$ & 50 & $10-30$ & 92 & $30-35$ & 0 & 0 & 130 & 35-above \\
\hline 32 & Post office area & 200 & $0-1$ & 92 & $2-10$ & 70 & $10-30$ & 85 & $30-35$ & 0 & 0 & 100 & 35-above \\
\hline 33 & $\begin{array}{l}\text { Min. of Agric } \\
\text { area }\end{array}$ & 260 & $0-1$ & 150 & $2-10$ & 45 & $10-30$ & 50 & $\begin{array}{l}30-35 \\
\text { above }\end{array}$ & 0 & 0 & 60 & 35-above \\
\hline 34 & $\begin{array}{l}\text { Ododosowapo } \\
\text { Amilegbe }\end{array}$ & 340 & $0-1$ & 100 & $2-10$ & 56 & $10-30$ & 43 & $30-35$ & 0 & 0 & 68 & 35-above \\
\hline 35 & Onikanga GRA & 1200 & $0-1$ & 1000 & $2-10$ & 1000 & $10-30$ & 55 & $30-35$ & 0 & 0 & 60 & 35-above \\
\hline 36 & $\begin{array}{l}\text { Sakama Niger } \\
\text { Rd }\end{array}$ & 20 & $0-1$ & 35 & $2-10$ & 330 & $10-30$ & 220 & $30-35$ & 0 & 0 & 270 & 35-above \\
\hline 37 & $\begin{array}{l}\text { Okaka Niger } \\
\text { Rd }\end{array}$ & 720 & $0-1$ & 1102 & $2-10$ & 180 & $10-30$ & 50 & $30-30$ & 0 & 0 & 99 & 30-above \\
\hline 38 & $\begin{array}{l}\text { Agbadam Lake } \\
\text { Rd }\end{array}$ & 50 & $0-1$ & 65 & $2-10$ & 90 & $10-30$ & 80 & $\begin{array}{l}30-35 \\
\text { above }\end{array}$ & 0 & 0 & 110 & $30-40$ \\
\hline 39 & $\begin{array}{l}\text { Abdulrasaq Rd } \\
\text { GRA }\end{array}$ & 200 & $0-1$ & 180 & $2-8$ & 140 & $8-30$ & 170 & $\begin{array}{l}30-35 \\
\text { above }\end{array}$ & 0 & 0 & 175 & 35-above \\
\hline 40 & $\begin{array}{l}\text { Unilorin } \\
\text { Garden }\end{array}$ & 650 & $0-1$ & 300 & $2-8$ & 50 & $8-30$ & 145 & $\begin{array}{l}30-35 \\
\text { above }\end{array}$ & 0 & 0 & 160 & 40-above \\
\hline
\end{tabular}


Geo-electric characteristics of Basement Complex rocks

\begin{tabular}{|c|c|c|c|c|c|c|c|c|c|c|c|c|c|}
\hline 41 & $\begin{array}{l}\text { Tipper Garage } \\
\text { area }\end{array}$ & 200 & $0-1$ & 310 & $2-8$ & 170 & $8-30$ & 300 & $\begin{array}{l}30-35 \\
\text { above }\end{array}$ & 0 & 0 & 350 & 30-above \\
\hline 42 & Behind Fed Sec. & 1000 & $0-1$ & 350 & $2-10$ & & $10-30$ & 128 & $30-35$ & 0 & 0 & 165 & 35-above \\
\hline 43 & $\begin{array}{l}\text { Odofin Lane } \\
\text { Basin }\end{array}$ & 100 & $0-11$ & & & & & 260 & $\begin{array}{l}30-35 \\
\text { above }\end{array}$ & 0 & 0 & 450 & 40-above \\
\hline 44 & $\begin{array}{l}\text { Water View } \\
\text { area }\end{array}$ & 100 & $0-1$ & 380 & $2-8$ & 240 & $8-30$ & 300 & $30-35$ & 0 & 0 & 370 & 35-above \\
\hline 45 & $\begin{array}{l}\text { Adelodun Rd } \\
\text { Fate }\end{array}$ & 140 & $0-1$ & 90 & $2-8$ & 55 & $8-30$ & 70 & $30-35$ & 0 & 0 & 92 & 35-above \\
\hline 46 & Edun area & 265 & $0-1$ & 130 & $2-8$ & 55 & $8-30$ & 78 & $30-35$ & 0 & 0 & 82 & 35-above \\
\hline 47 & $\begin{array}{l}\text { Behind } \\
\text { Amusement } \\
\text { Park }\end{array}$ & 35 & $0-1$ & 23 & $2-10$ & 33 & $10-30$ & 40 & $30-35$ & 0 & 0 & 45 & 35-above \\
\hline 48 & $\begin{array}{l}\text { Mustapha } \\
\text { Idiagbede Basin }\end{array}$ & 140 & $0-1$ & 100 & $2-10$ & 70 & $10-30$ & 95 & $30-35$ & 0 & 0 & 120 & 35-above \\
\hline 49 & $\begin{array}{l}\text { Adeleye Str. } \\
\text { GRA }\end{array}$ & 800 & $0-1$ & 300 & $2-10$ & 55 & $10-30$ & 120 & $30-35$ & 0 & 0 & 130 & 35-above \\
\hline 50 & GSS Area & 80 & $0-1$ & & $2-10$ & 28 & $10-30$ & 40 & $30-35$ & 0 & 0 & 60 & 35-above \\
\hline 51 & $\begin{array}{l}\text { Kwara ADP } \\
\text { area }\end{array}$ & 300 & $0-1$ & 360 & $2-10$ & 55 & $10-30$ & 60 & $30-35$ & 0 & 0 & 100 & 35-above \\
\hline 52 & $\begin{array}{l}\text { Ile eleru } \\
\text { Ojagbooro }\end{array}$ & 40 & $0-1$ & & $2-10$ & 35 & $10-30$ & 30 & $30-35$ & 115 & & 35 & 35-above \\
\hline 53 & Office Rd GRA & 300 & $0-1$ & 97 & $2-10$ & 32 & $10-30$ & 51 & $\begin{array}{l}30-35 \\
\text { above }\end{array}$ & 0 & 0 & 55 & 40-above \\
\hline
\end{tabular}

\subsection{Geo-electric Succession and their characteristics in Ilorin Metropolis}

\subsubsection{Top Lateritic Soil and Lateritic Clay}

The average resistivity and thickness values of top lateritic soil in Apata Yakuba, Ganiki Sango and Royal Valley are $662 \mathrm{ohm}-\mathrm{m}$ and $1 \mathrm{~m}$ respectively which indicate lower clay proportion. The average resistivity and thickness values of top lateritic soil in Elekoyangan, Sango area and Oyun area are 106 $\mathrm{ohm}-\mathrm{m}$ and $2 \mathrm{~m}$ respectively which indicated that the predominant composition of the top soil is lateritic clay. In Apata Yakuba, Ganiki Sango and Royal Valley, the average resistivity values and thickness of lateritic layer are $250 \mathrm{ohm}-\mathrm{m}$ and $4 \mathrm{~m}$ which implies that the layers composed of clayey sand. Also, the average resistivity and thickness values of top lateritic soil in Alagbado, Okelele and Olorunshogo areas are 107 ohm-m and $2 \mathrm{~m}$ respectively which indicates that the predominant composition of the top soil is lateritic clay. The average resistivity and thickness values of top lateritic soil in Agbabiaka area, Kilanko area and Tanke area are $107 \mathrm{ohm}-\mathrm{m}$ and $2 \mathrm{~m}$ respectively which is an indication that the predominant composition of the top soil is lateritic clay. Figure 3 shows map of the spatial distribution pattern of lateritic clay in the study area as it varies from one location to another. 


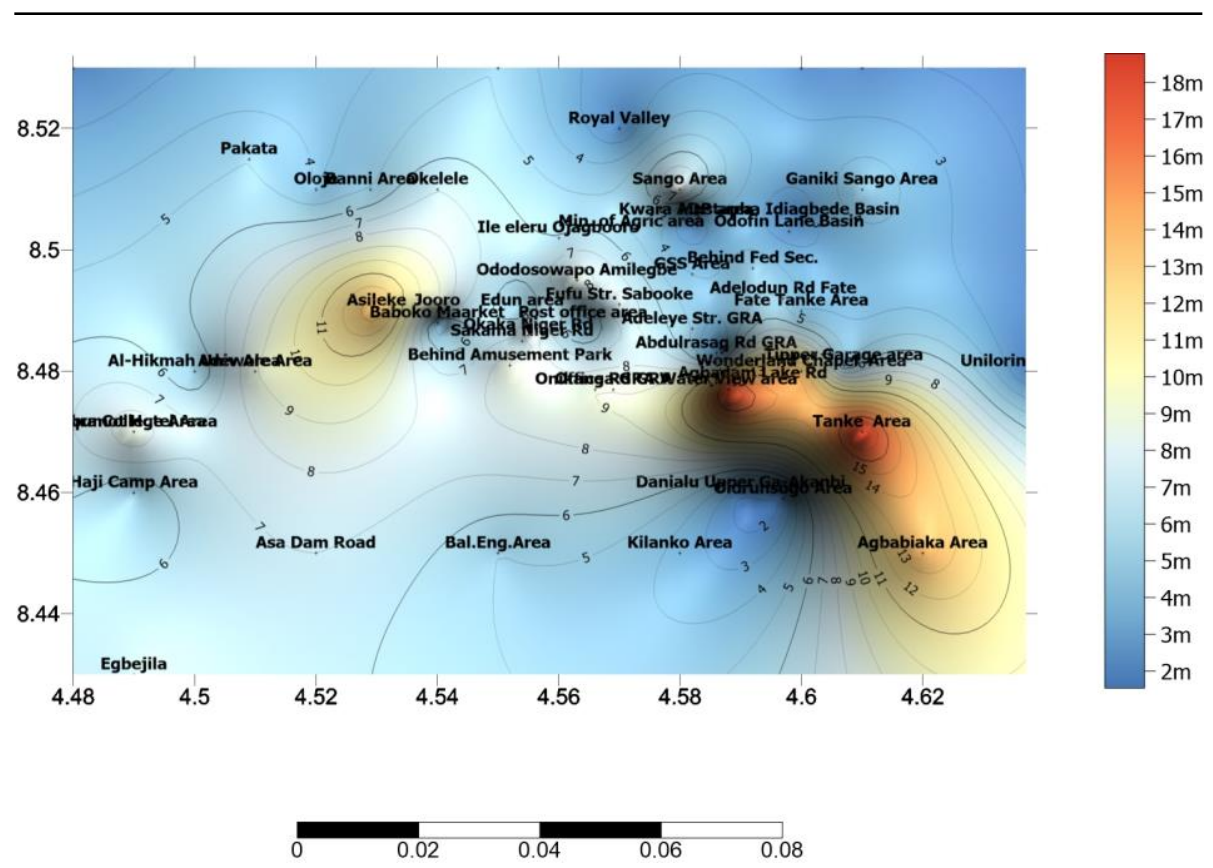

Fig 3. Distribution pattern of Lateritic clay depth (m) in Ilorin

\subsubsection{Weathered Basement}

In Apata Yakuba, Ganiki Sango and Royal Valley, the weathered basement average resistivity and thickness are $105 \mathrm{ohm}-\mathrm{m}$ and $18 \mathrm{~m}$ which indicates a saturation characterized by a moderately low resistivity layer. The weathered basement average resistivity and thickness are $103 \mathrm{ohm}-\mathrm{m}$ and $18 \mathrm{~m}$ in Elekoyangan, Sango area and Oyun area, suggesting some level of saturation characterized a moderately lower resistivity layer. In Alagbado, Okelele and Olorunshogo, the weathered basement average resistivity and thickness are $51 \mathrm{ohm}-\mathrm{m}$ and $22 \mathrm{~m}$, respectively. This agrees with the findings of Ogunlana and Talabi (2014), indicating that the material composition is largely clay, sandy clay and clayey sand. This is evidenced in the high degree of water logging of this area, particularly in dry season. In Agbabiaka, Kilanko and Tanke area of the city. The weathered basement average resistivity and thickness are $135 \mathrm{ohm}-\mathrm{m}$ and $30 \mathrm{~m}$ respectively, which indicates existence of some degree of fractures and water saturation weathered basement. The weathered basement average resistivity and thickness for Danialu and Fate Tanke are $158 \mathrm{ohm}-\mathrm{m}$ and $15 \mathrm{~m}$ respectively, indicating a saturation characterized by a moderately low resistivity layer. Figure 4 shows map of the spatial distribution pattern of weathered basement in the study area as it varies from one location to another. 

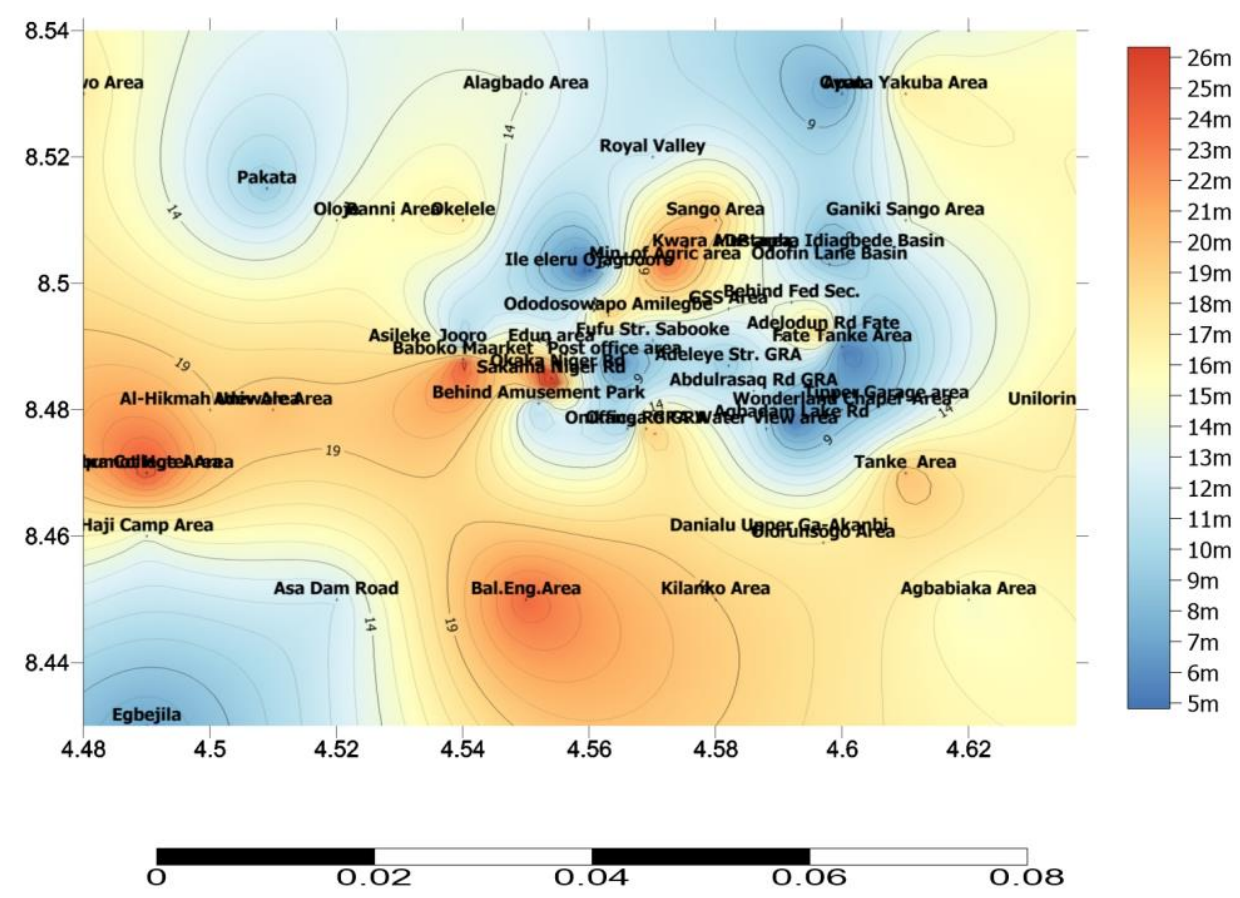

Fig 4. Distribution pattern of Weathered Basement Depth (m) in Ilorin

\subsubsection{Fairly Hard Basement}

The fairly hard basement in Elekoyangan, Sango area and Oyun area, average and thickness resistivity are $167 \mathrm{ohm}-\mathrm{m}$ and $30 \mathrm{~m}$. This falls within the weathered and fresh basement rock which is also characterized by potential aquiferous units and hard rock in the areas. Also, its resistivity and thickness values are $3390 \mathrm{hm}-\mathrm{m}$ and $30 \mathrm{~m}$, the result agree with Oyedele and Olayinka (2012) that the groundwater potential of the aquifer may be significantly enhanced if the geo-electric basement has a fairly low resistivity. Relatively low values of geo-electric basement resistivity $(200-640 \Omega \mathrm{m})$ are indicative of good groundwater potential. The fairly low bedrock resistivity confirms the presence of fractures and hence water contained within the fissures (Becson and Jones, 1988; Olayinka and Olorunfemi, 1992; Ayodele and Olayinka, 2012). Figure 5 shows map of the spatial distribution pattern of fairly hard basement in the study area as it varies from one location to another. 


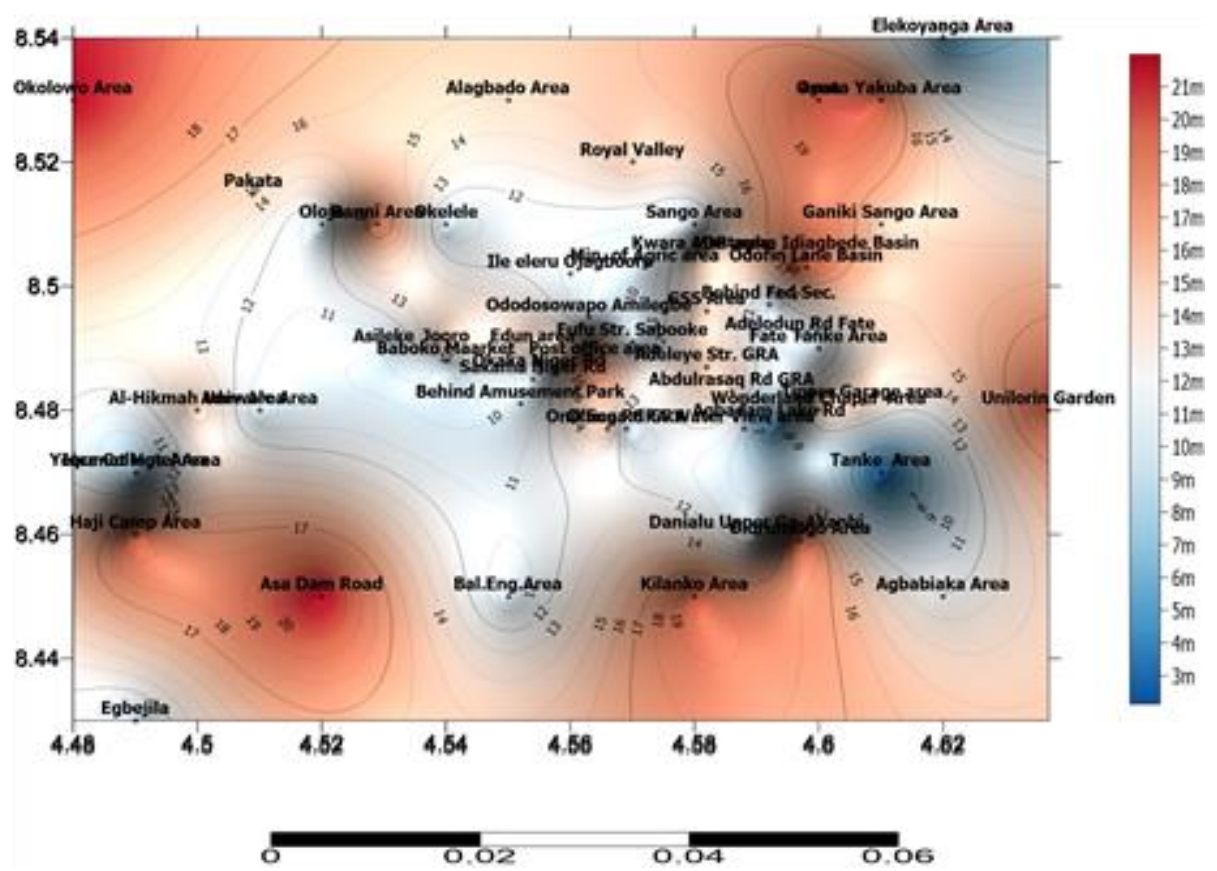

Fig 5. Distribution pattern of Fairly Weathered Basement Depth (m) in Ilorin

\subsubsection{Thin Fractured}

In Alagbado, there is a presence of thin fracture zone which indicates a good potential aquiferous units in the area. Fate Tanke area also show thin fractured zone in the study area which served as reservoir in the area. Oloje area have thin fractured zone. The resistivity and the thickness values are $60 \mathrm{ohm}-\mathrm{m}$ and $35 \mathrm{~m}$ which indicates that the area are water bearing zone due to its low resistivity values. The coloured part of Figure 6, shows map of the spatial distribution pattern of thin fractured in Ilorin, while the plain area are the locations without thin fracture zone in the study area. 


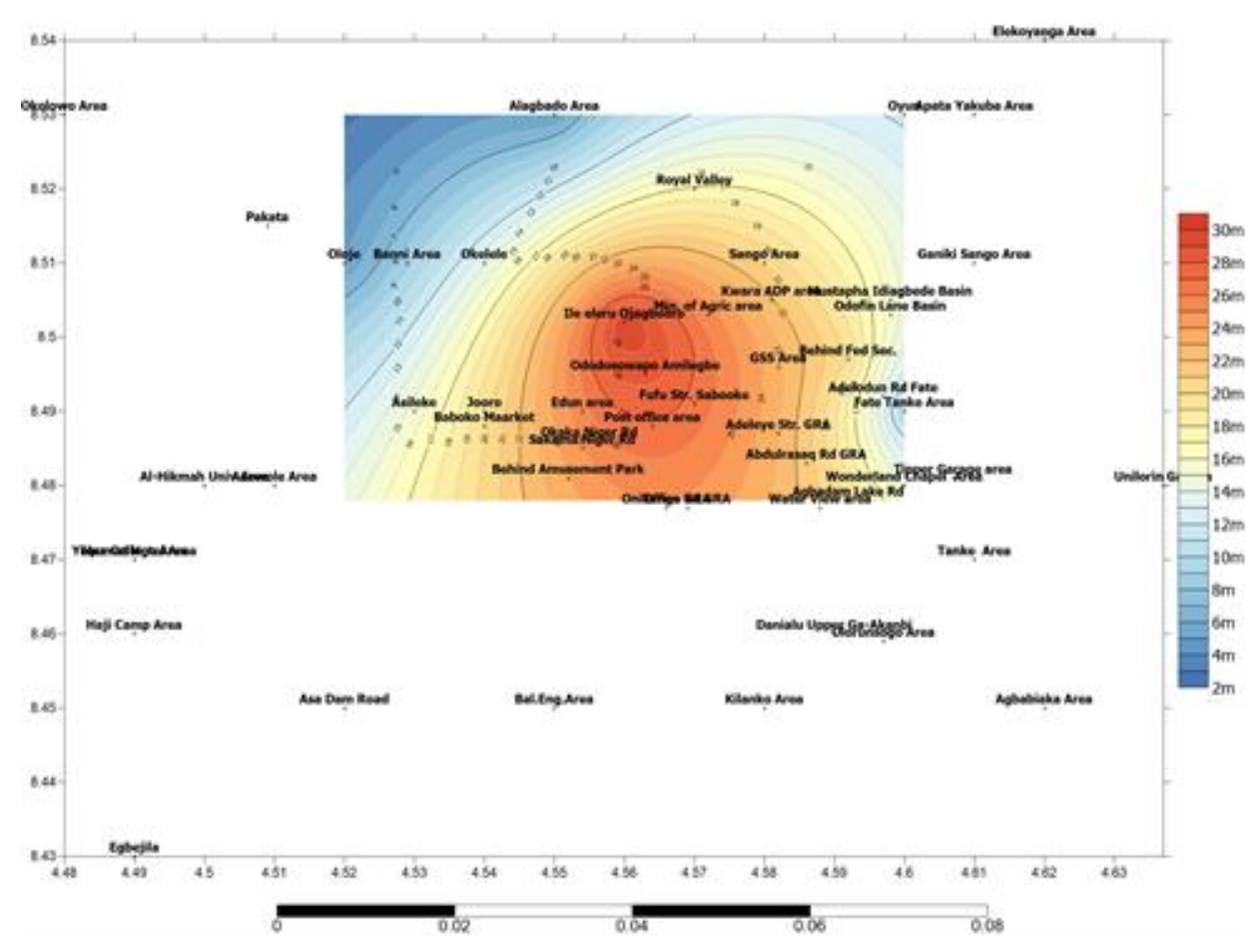

Fig 6. Distribution pattern of Thin Fractured Depth (m) in Ilorin

\subsubsection{Hard Basement}

The hard basement in Alagbado, Okelele and Olorunshogo, also varies and the average resistivity and thickness values are $100 \mathrm{ohm}-\mathrm{m}$ and $38 \mathrm{~m}$ which indicate fine grained with intercalation of sandy clay. Fresh hard rock is the last layer in Apata Yakuba, Ganiki Sango and Royal Valley, the section is relatively deep in the area and average resistivity and thickness values are $307 \mathrm{ohm}-\mathrm{m}$ and $35 \mathrm{~m}$, the resistivity values are somehow high because of its crystalline nature. The hard basement in Agbabiaka area, Kilanko area and Tanke area also varies and the average resistivity and thickness values are $240 \mathrm{ohm}-\mathrm{m}$ and $41 \mathrm{~m}$ which indicate fine grained with intercalation of sandy clay. The hard rock average resistivity and thickness values for Danialu, Fate Tanke and Wonderland Chapel area, are $4390 \mathrm{hm}-\mathrm{m}$ and $30 \mathrm{~m}$. The result agrees with Oyedele and Olayinka (2012), that the groundwater potential of the aquifer may be significantly enhanced if the geo-electric basement has a fairly low resistivity. Relatively low values of geo-electric basement resistivity are indicative of good groundwater potential and the fairly low 
bedrock resistivity confirms the presence of fractures, which shows that water is contained within the fissures (Becson and Jones, 1988, and Olayinka and Olorunfemi, 1992; Ayodele and Olayinka, 2012). Figure 7 shows the spatial distribution pattern of hard basement in the study area as it varies from one location to another.

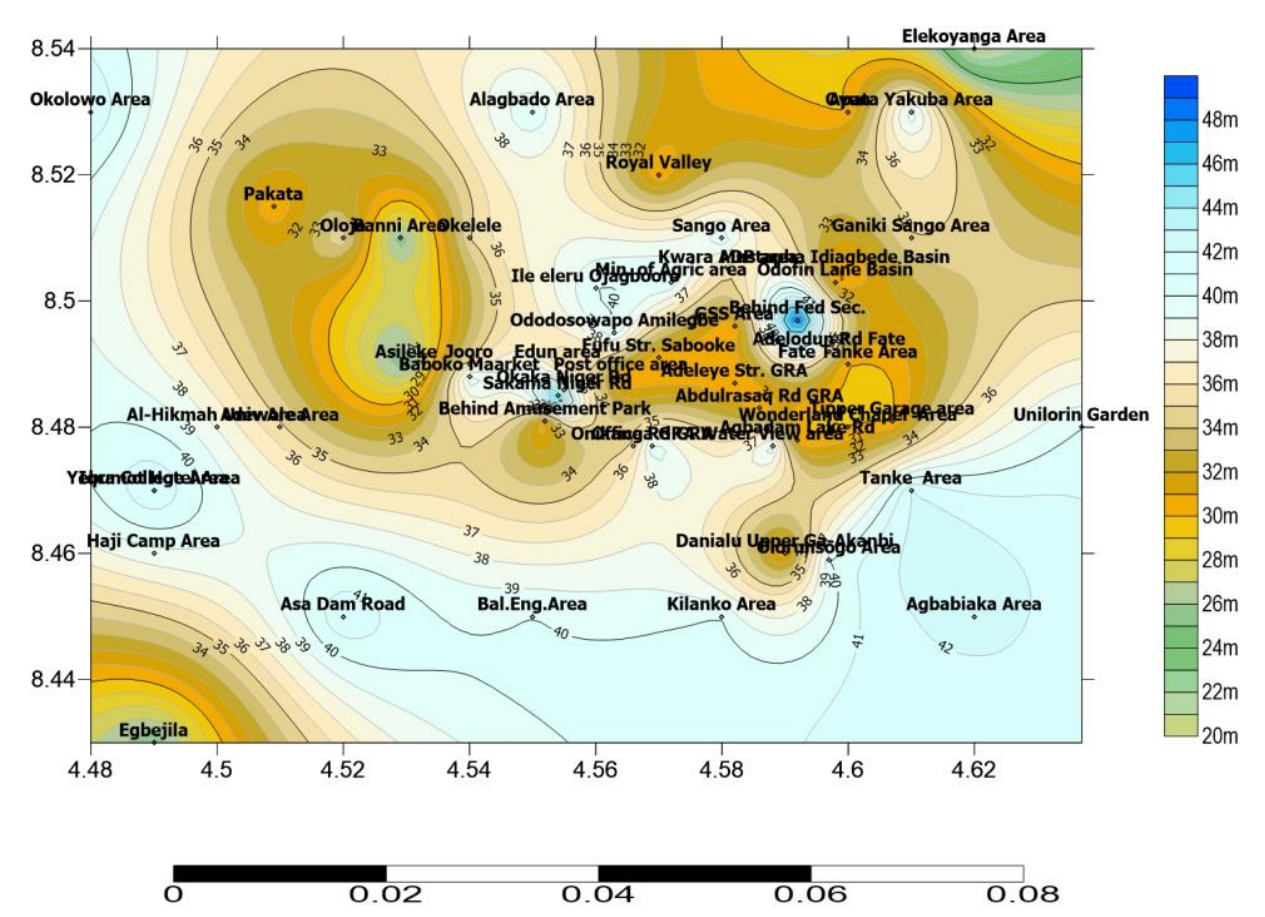

Fig 7. Spatial Distribution Pattern of Hard Basement Depth (m) in Ilorin

\section{Conclusion}

In conclusion, understanding the spatial distribution of geo-electric succession, especially in a large area is a key to maximizing groundwater prospecting. This study has revealed four to six geo-electric successions in Ilorin metropolis and took a step further to present a spatial distribution pattern of the identified layers in the study area. As revealed by the study, from the third layer to the sixth layer shows good groundwater potential. In addition, the resistivity values obtained shows that there are economically viable groundwater resources in the study area, especially in the weathered basement, fairly hard basement, thin fractured and hard basement lithology. Although, the level of groundwater availability varies from one location to the 
other as the depth and resistivity of these layers varies from place to place. The spatial distribution pattern of the geo-electric succession presented in this study would aid driller in siting boreholes in Ilorin metropolis, without necessarily conducting geophysical survey, which will in turn reduce the cost of drilling borehole in the study area.

Acknowledgements The authors appreciate the managements of Kwara State Ministry of Water Resources and Lower Niger River Basin and Rural Development Authority, Ilorin for providing us the data for this work.

\section{References}

Abiola O, Ogunribido THT, Omoniyi BA, Ikue PO. 2013. Geo-electric assessment of groundwater prospects in Supare Estate, Supare Akoko, South Western, Nigeria. Journal of Geosciences 3(1):23-33.

Adiat KAN, Olayanju, GM., Omosuyi, GO., Ako BD. 2009. Electromagnetic profiling and electrical resistivity soundings in groundwater investigation of a typical Basement Complex-a case study of Oda Town Southwestern Nigeria. Ozean Journal of Applied Sciences, 2(4): 333-359.

Amaresh, Kr. S. and Ravi Prakash, S. 2003. An integrated approach of remote sensing, geophysics and GIS to evaluation of groundwater potentiality of Ojhala Subwatershed, Mirzapur District, U.P., India. Water Resources, Map India Conference 2003.

Anomoharan, O. 2011. Determination of groundwater potential in Asaba, Nigeria using surface geo-electric sounding, International Journal of Physical Sciences, 6: 7651-7656.

Anomoharan, O. 2013. Geophysical investigation of groundwater potential in Ukelegbe, Nigeria. Journal of Applied Sciences, 13(1): 119-125.

Bose KN., Chatterjee D., and Sen AK. 1973. Electrical resistivity surveys for groundwater in the Aurangabad Sub-division, Gaya District, Bihar, Indian pp. 171-181.

Ifabiyi, IP. and Ahmed, YA. 2011. Determination of household water demand in a traditional city: Examples from western axis of Ilorin Nigeria. Asian- African Journal of Econometrics and Economics, 11(2):395-408.

Ifabiyi, IP. and Ashaolu, ED. 2013. Analysis of the impacts of rainfall variability on public water supply in Ilorin, Nigeria. Journal of Meteorology and Climate Science, 11(1):18-26.

Krishnamurthy, J., Venkataesa Kumar, N., Jayraman, V. and Manivel, M. 1996. an approach to demarcate groundwater potential zones through remote sensing and GIS. International Journal of Remote Sensing, 17(10):1867-1884.

Murthy, KSR. 2000. Groundwater potential in a semi-arid region of Andhra Pradesh: A geographical information system approach, International Journal of Remote Sensing, 21(9):1867-1884.

Ogundana, AK. and Talabi, AO. 2014. Geo-electric characterization of aquiferous units and its implication on groundwater potential of Owo, Southwestern Nigeria. American Journal of Water Resources, 2 (2): 37-40.

Oladapo, MI., Adeoye-Oladapo, OO. and Mogaji, KA. 2009. Hydrogeophysical study of the groundwater potential of Ilara-Mokin Southwestern Nigeria. Global Journal of Pure and Applied Sciences, 15(2):195-204.

Olayinka AI, and Olorunfemi MO. 1992. Determination of geo-electric characteristics in Okene area and implications for borehole Siting. Journal of Mining and Geology. 28(2):403-411.

Olorunfemi MO. 1990. The hydrogeological implication of topographic variation with overburden thickness in Basement Complex area of SW Nigeria. Journal and Mining and Geology. 26 (1) 
Olorunfemi MO. and Fasuyi SA. 1993. Aqufier types and geo-electric/hydrogeologic characteristics of part of central basement terrain of Nigeria (Niger State). Journal of Africa Earth Sciences, 16 (3): 309-317.

Omosuyi, GO., Ojo, JS. and Enikanselu, PA. 2003. Geophysical investigation for groundwater around Obanla - Obakekere in Akure Area within the Basement Complex of South-Western Nigeria. Journal of Mining and Geology. 39(2):109-116.

Otobo, E. and Ifedili, SO. 2005. The Vertical Electrical Sounding: A Viable tool for the investigation of fresh groundwater in the saline water environment with particular references to the community along Warri River, Journal of Nigerian Association of Mathematics and Physics, 5: 437-442.

Oyedele, EAA. and Olayinka, AI. 2012. Statistical evaluation of groundwater potential of AdoEkiti, South Western Nigeria. Translational Journal of Science and Technology, 12(6):110127.

Oyedele, EAA., Oyedele, T. and Oyedele, K. 2013. Geo-electrical data analysis to demarcate groundwater pockets in Ado-Ekiti, Southwest, Nigeria. International Journal of Water Resources and Environmental Engineering, 5(11): 609-615.

Saraf, AK. and Chaudhary, PR. 1998. Integrated remote sensing and GIS for groundwater exploration and identification of artificial recharges sites, International Journal of Remote Sensing, 19(10):1825-1841.

Shahid, S. and Nath, SK. 2002. GIS Integration of remote sensing and electrical sounding Data for hydrogeological exploration, Journal of Spatial Hydrology, 2(1): 1-12. 